\title{
COMPARISON OF HIGH SENSITIVITY C-REACTIVE PROTEIN VALUE FOR STEROID SENSITIVE NEPHROTIC SYNDROME PATIENTS WITH STEROID RESISTANT
}

\author{
Fifi Febria Ningsih*, Rosmayanti S. Siregar, Yunnie Trisnawati \\ Department of Pediatrics Adam Malik Hospital, Faculty of Medicine, \\ Universitas Sumatera Utara, Medan, Indonesia \\ Email : fifi_febria@yahoo.com
}

Backgroud : Nephrotic syndrome (NS) is the most common glomerulopathy in childhood. The incidence of NS in the United States and United Kingdom is 2-7 new cases per 100,000 children per year, with a prevalence ranging from 16 cases per 100,000 children, and is found to be higher in developing countries. Nephrotic syndrome is a chronic disease that requires longterm monitoring because one of the complications that can be caused is cardiovascular complications caused by hyperlipidemia. High Sensitivity C-Reactive Protein (hs-CRP) can be used as a cardiovascular predictor in NS patients.

Objective : To determine the differences in the value of hs-CRP in steroid sensitive nephrotic syndrome patients with steroid resistance.

Methods : Case control design in 36 pediatric patients with nephrotic syndrome who came to the outpatient and inpatient unit of H. Adam Malik Hospital Medan from August 2020 to December 2020. Sampling using consecutive sampling technique, conducted interviews with parents, physical and laboratory examinations to confirm the diagnosis of steroid sensitive and steroid resistant nephrotic syndrome. An unpaired t-test and Mann-Whitney test were analyzed to assess the comparison between variables.

Result : All NS patients were 36 subjects, 25 subjects $(69.4 \%)$ were male and 11 subjects $(30.5 \%)$ were female. The mean age of the study subjects for steroid sensitive NS patients was 8.4 (SD 4.8) years, whereas for steroid-resistant NS patients was 10.4 (SD 4.7) years. There was no significant difference between the hs-CRP value of steroid sensitive nephrotic syndrome patients with steroid resistance.

Conclusion : There is no significant difference between the hs-CRP value of steroid sensitive nephrotic syndrome patients with steroid resistance.

Keywords : children, nephrotic syndrome, hs-CRP.

\section{BACKGROUNDS}

Nephrotic syndrome (NS) is one of the most common glomerular diseases in children. ${ }^{1}$ Nephrotic syndrome is classified based on response to steroid therapy, pattern of relapse, histopathology, or genetic mutation. Based on the clinical response to steroids, NS was categorized into steroid sensitive and steroid resistant. ${ }^{2}$ Most of the NS in children was steroid sensitive NS, 10-20\% did not respond to steroids called steroid resistant NS with $>50 \%$ failing to achieve remission which continued to end stage kidney disease. ${ }^{3}$

The incidence of NS in the United States and United Kingdom is 2-7 new cases per 100,000 children per year, with a prevalence of around 16 cases per 100,000 children, 
and is found to be higher in developing countries. ${ }^{4}$ In Indonesia it is reported to be 6 per 100,000 per year in children younger than 14 years. The ratio of boys and girls is $2: 1 .^{5}$ In Haji Adam Malik General Hospital, the incidence of nephrotic syndrome cases from 2011-2012 was 5.8 cases per 100,000 children. $^{6}$

Nephrotic syndrome is a chronic disease that requires long-term monitoring because one of the complications it can cause is cardiovascular complications caused by hyperlipidemia, increased thrombogenesis and endothelial dysfunction. Hyperlipidemia is closely related to the degree of hypoalbuminemia and persistent proteinuria or renal insufficiency. ${ }^{1}$ This is related to the patient's response to given glucocorticoid treatment, whether it is steroid sensitive or steroid resistant. Hyperlipidemia is more common in children with relapsing NS or experiencing resistance to corticosteroid therapy where levels of the lipid profile are persistently high and increase the risk of developing atherosclerosis. ${ }^{7}$

The characteristics of hyperlipidemia in NS are an increase in total cholesterol, low-density lipoprotein (LDL), very-low-density lipoprotein (VLDL), and intermediate-density lipoprotein with an increase in the LDL/HDL ratio. ${ }^{8}$ Hyperlipidemia can stimulate the release of inflammatory mediators that lead to atherosclerosis. Therefore, early detection is needed to prevent disease severity, namely by examining the lipid profile and High sensitivity C-Reactive Protein (hs-CRP). High sensitivity C-Reactive Protein is a method of examining CRP levels that are more sensitive in small amounts. ${ }^{9}$ There are several studies assessing hs-CRP in NS patients such as that conducted by Wasilewska 2007 which reported an increase in hs-CRP before treatment and decreased after 3 - 4 weeks of glucocorticoid treatment. ${ }^{10}$ Then a study conducted by Thakur 2011 which reported that increased hs-CRP could be used as a prognostic in coronary heart disease.

The atherogenic lipid profile in adults with NS is associated with an increased risk of cardiovascular events, such as myocardial infarction. Several reports of myocardial infarction have also been documented in children. However, persistent lipid abnormalities in patients with NS, even in remission, the risk of long-term cardiovascular events for children with NS remains unclear. ${ }^{9}$

Despite previous studies, further evaluation is needed to develop recommendations for hs-CRP testing in nephrotic syndrome. There has never been a study comparing the value of hs-CRP in steroid sensitive and steroid resistant NS. This led the researchers to look for the difference between the two, steroid-sensitive and steroid-resistant NS patients at Haji Adam Malik General Hospital Medan.

\section{MATERIALS AND METHODS}

\section{Subjects and Methods}

The design of this study was a case control study that assessed the difference in the value of hs-CRP between children with steroid-sensitive NS and steroid-resistant NS at the Haji Adam Malik General Hospital. The research was conducted at the Haji Adam Malik General Hospital from July 2020 to December 2020. The target population is children aged 1 - 18 years with a diagnosis of steroid sensitive and steroid resistant NS. The affordable population in this study were pediatric patients with a diagnosis of NS who came to the outpatient unit and the inpatient unit of Haji Adam Malik General Hospital. The research sample is an affordable population that meets the inclusion criteria. The sample was selected by means of non-probability sampling, namely consecutive sampling technique. The exclusion criteria in this study were NS patient relapses, sepsis, diabetes mellitus and obesity. 


\section{Ethical Considerations}

Our study was approve by Ethical Commision of Medical Faculty of Sumatera Utara University.

\section{Statistical Analysis}

Data was statistically analyzed using SPSS software version 22.0 (Statistical Package for Social Sciences) for windows. Descriptive statistics were expressed in the form of mean \pm standard deviation (SD); while for categorical data they were presented in the form of frequency. Comparisons between groups for continuous variables, normally distributed data were performed by T-test or Mann-Whitney test for the not normally distributed data with Pvalue of $(<0.05)$ was considered as a significant difference.

\section{RESULTS}

A total of 36 patient were included in this study with 18 subjects with sensitive steroid NS and 18 subjects with resistant steroid NS. From all of the subjects, 25 (69.4\%) subjects were male, $11(30.5 \%)$ subjects female. The mean age of the study subjects for steroid sensitive NS patients was 8.4 (SD 4.8) years, whereas for steroid-resistant NS patients was 10.4 (SD 4.7) years. The mean body weight in steroid sensitive NS patients was 28.9 (SD 13.1) and steroidresistant SN 37.2 (SD 16.1), while for the height of each group were 123.2 (SD 24.6) and 135.8 (SD 22.7). In the hematological parameters, there was no significant difference between steroid-sensitive and steroid-resistant NS patients, where the hemoglobin for each group was 12.3 (8.1-19.2) and 14 (8.3-17.4), while for the number of leukocytes $13.270(5,750)-35,820)$ and 10,420 (6,040-23,000). In steroid-sensitive NS creatinine levels were $0.5 \mathrm{mg} / \mathrm{dL}(0.2-2.2)$ and steroid-resistant NS was $0.5 \mathrm{mg} / \mathrm{dL}(0.4-1)$. In our study subjects there was no significant difference in lipid profile values in the two groups. Where in steroid-sensitive NS patients the median cholesterol value was $225 \mathrm{mg}$ / dL, triglycerides $204.5 \mathrm{mg} / \mathrm{dL}, \mathrm{HDL} 49.5 \mathrm{mg} / \mathrm{dL}$ and LDL $141 \mathrm{mg} / \mathrm{dL}$. Whereas in the steroid-resistant NS group the median cholesterol was 232 $\mathrm{mg} / \mathrm{dL}$, triglycerides $154.5 \mathrm{mg} / \mathrm{dL}$, HDL $46.5 \mathrm{mg} / \mathrm{dL}$ and LDL $164.5 \mathrm{mg} / \mathrm{dL}$.

Based on the hs-CRP value data, it was found that the median hs-CRP value in the two groups was still in the normal range, namely $0.1 \mathrm{mg} / \mathrm{dL}$ and $0.05 \mathrm{mg} / \mathrm{dL}$, with the minimum and maximum values in the two groups respectively $0-2.6 \mathrm{mg} / \mathrm{dL}$ and 0 $2.3 \mathrm{mg} / \mathrm{dL}$. The results of statistical analysis using the Mann-Whitney test showed that there was no significant difference in the hs-CRP value in the two groups ( $p>0.05)$.

\section{DISCUSIONS}

Nephrotic syndrome (NS) is the most common glomerulopathy seen in childhood. ${ }^{11}$ In our study, all NS patients were 36 subjects, 25 subjects (69.4\%) were male and 11 subjects $(30.5 \%)$ were female. This is consistent with the research of Banh et al. 2016 which found that the percentage of NS by sex in 3 study groups, namely in Europe, South Asia and Southeast Asia respectively with male sex, namely $61.3 \%, 64.6 \%$ and $62.3 \% .{ }^{12}$ Average age of research subjects for steroid sensitive NS patients it was 8.4 (SD 4.8) years, whereas for steroid-resistant NS it was 10.4 (SD 4.7) years. This is in accordance with the research of Zhou et al. 2018, where the mean age of $\mathrm{SN}$ patients was $8.9 \pm 1.6$ years. ${ }^{13}$

In this study, the average body weight of steroid-sensitive NS patients was 28.9 (SD 13.1) and steroid-resistant NS 37.2 (SD 16.1), while the height of each group was 
123.2 (SD 24.6) and 135.8 (SD 22.7). In the research of Kniazewska et al. in the SN patients studied, 1 patient was obese (body mass index (BMI) above the 95th percentile), 3 (10\%) overweight (90-95th percentile BMI), and $2(6.6 \%)$ with short stature (height below percentile $5) .{ }^{11}$ In our study, there was no difference in nutritional status in the two groups, but on the exclusion criteria, patients with obese nutritional status were not included as study subjects because it could affect the assessment of lipid profile levels in NS patients.

In the hematological parameters, there was no significant difference between steroid-sensitive and steroid-resistant NS patients, where the hemoglobin for each group was $12.3(8.1-19.2)$ and $14(8.3-17.4)$, while for the number of leukocytes $13.270(5,750)$ $-35,820)$ and $10,420(6,040-23,000)$. In a 2013 Turkish study, similar results were also obtained with the mean hemoglobin value of $13.0 \pm 2.0(\mathrm{~g} / \mathrm{dl})$ and leukocytes $7,800(2,000-11,000)$ for the three study groups, namely complete remission, partial remission and no remission. Also with albumin levels, in this study there was also no significant difference between steroid sensitive and steroid resistant NS.

From the results of blood pressure measurements both groups were found to be within normal limits. This is consistent with the results of research by Kniazewska et al. where the blood pressure in both groups of study subjects was within normal limits according to age, sex, and height. ${ }^{11}$ The incidence of hypertension in NS alone ranges from $15-20 \%$ with an increase in creatinine and urea levels by $32 \%$ which is temporary.

In this study, blood chemistry parameters including urea and creatinine were found in the normal range and there was no significant difference between the two groups. In steroid-sensitive NS creatinine levels were $0.5 \mathrm{mg} / \mathrm{dL}(0.2-2.2)$ and steroid-resistant NS was $0.5 \mathrm{mg} / \mathrm{dL}(0.4-1)$. Research by Merouani et al. 2003, found in the case of NS plasma creatinine levels were within normal limits $(27-88 \mu \mathrm{mol} / \mathrm{L})$ and did not differ between patients on treatment 49.4 (2.0) $\mu \mathrm{mol} / \mathrm{L}$ and not on treatment 49.0 (4.3) $\mu \mathrm{mol} / \mathrm{L}$.

In more than $80 \%$ of patients NS is minimal changes NS characterized by normal kidney histology on examination under light microscopy. The rest were focal segmental glomerulosclerosis (GFS, 7\%), mesangioproliferative glomerulonephritis (5\%), membranoproliferative glomerulonephritis $(7 \%)$ and membranous glomerulonephropathy (1$2 \%$ ). The underlying pathology in patients with steroid-resistant NS is the type of GFS. ${ }^{5}$ Impaired renal function in the presence of a decrease in glomerular filtration rate can occur in the GFS type.

The lipid metabolism disorders found in nephrotic syndrome include elevated levels of cholesterol, LDL, IDL, VLDL, phospholipids and triglycerides. HDL values can be found low, normal or sometimes high. The lipid metabolism disorders in NS can improve with treatment, but can persist during periods of remission. ${ }^{11}$ Research Merouani et al. 2003, obtaining plasma lipid profiles in 25 children with NS at remission, with or without active prednisone treatment, compared to a population of the same age showed that total and LDL cholesterol levels were above the 95th percentile for age and sex in 12 of 25 patients (48\%), 7 of whom had apolipoprotein B and triglyceride concentrations above the 95th percentile. In the 2013 Turkish study, in the 3 study groups studied, there was a decrease in lipid profile values after 12 months of monitoring. ${ }^{14}$

In the research of Lawang et al. In 2008, at 6 months of monitoring, patients who had previously experienced remission at 8 weeks of treatment, from 30 study subjects, 12 subjects experienced a relapse marked by a return to increase in the lipid profile 
values of NS patients compared to controls. ${ }^{15}$ From the results of this study, for determine when the improvement of the occurrence of hyperlipidemia can not be determined with certainty.

In our study subjects there was no significant difference in lipid profile values in the two groups. Where in steroid-sensitive NS patients the median cholesterol value was $225 \mathrm{mg} / \mathrm{dL}$, triglycerides $204.5 \mathrm{mg} / \mathrm{dL}$, HDL $49.5 \mathrm{mg} / \mathrm{dL}$ and LDL $141 \mathrm{mg} / \mathrm{dL}$. Whereas in the steroid-resistant NS group the median cholesterol value was $232 \mathrm{mg} / \mathrm{dL}$, triglycerides $154.5 \mathrm{mg} / \mathrm{dL}$, HDL $46.5 \mathrm{mg} / \mathrm{dL}$ and LDL $164.5 \mathrm{mg} / \mathrm{dL}$. According to the National Cholesterol Education Program (NCEP) the values above are still above normal values except for HDL, namely total cholesterol $\geq 200 \mathrm{mg} / \mathrm{dL}, \mathrm{LDL}>130 \mathrm{mg} / \mathrm{dL}$, triglycerides $\geq 100 \mathrm{mg} / \mathrm{dL}$ and $\mathrm{HDL} \leq 40 \mathrm{mg} / \mathrm{dL} .{ }^{16}$ Abnormalities this suggests that NS patients have a higher risk of developing atherosclerotic lesions, although this is a matter of debate. While some clinical reports suggest a high incidence of ischemic heart disease in adult NS patients, others have found no increased risk. ${ }^{17}$ The occurrence of hyperlipidemia with associated morbidity is of particular concern and raises the question of whether to treat it or not. In our study subjects none of the patients received lipid-lowering drugs.

The increased risk of heart and blood vessel disease due to atherosclerosis is evidence of impaired function of the vascular endothelium in NS patients. In this case, to detect atherosclerosis early, the American Heart Association (AHA) recommends the hs-CRP examination, which can measure the CRP value at a concentration of $\leq 0.3 \mathrm{mg} / \mathrm{L}$. A serum hs-CRP level below $1 \mathrm{mg} / \mathrm{L}$ indicates a low risk, 1 to $3 \mathrm{mg} / \mathrm{L}$ moderate risk, and 3 to $10 \mathrm{mg}$ / L very high cardiovascular risk. ${ }^{10}$

In our study, the hs-CRP value was found in steroid sensitive NS patients $0.1(0.0-2.6)$ and in the steroid-resistant NS group $0.05(0.0-2.3)$ and there was no significant difference between the two ( $p>0.05$ ). From these results it can be classified that NS patients in this study were included in the low risk category for cardiovascular events $(<1 \mathrm{mg} / \mathrm{dL})$. This is consistent with the results of research by Kniazewska et al. Where the hs-CRP value after treatment was found to be normal and the same as the control group.

The study of Patel et al, children with NS showed an increase in hs-CRP and found a positive correlation with hypercholesterolemia. The value of hs-CRP in SN patients was between $0.9-9.7 \mathrm{mg} / \mathrm{L}$ with a median of $1.92 \mathrm{mg} / \mathrm{L}$, where $70 \%$ had hs-CRP levels of $1-3 \mathrm{mg} / 1$ and 55\% $3 \mathrm{mg} / 1$. Whereas in controls the value of hs-CRP was between $0.25-1 \mathrm{mg} / 1$ with a median of $0.56 \mathrm{mg} / 1.30$ A 2004 Brazilian study reported that children with recurrence of nephrotic syndrome showed a significant increase in hs-CRP levels and decreased after treatment. ${ }^{18}$ However, from these studies there was no difference in the value of hs-CRP in patients with steroid-sensitive NS and steroid-resistant NS. This proves that the hs-CRP value cannot be used to compare the outcome of cardiovascular events as complications in both steroid-sensitive and steroid-resistant NS patients. As is known, the persistence of hyperlipidemia that occurs is greater in steroid-resistant NS patients. ${ }^{7}$

In the 2017 Horas study, testing the hs-CRP parameter as a predictor of the severity of coronary lesions and determining the cut-off point for severe lesions. This study found that by using the ROC curve, hs-CRP has a fairly strong predictive value, with an under curve area of 0.798 and $P=0.031$. Then it was found that the cut-off point that had the highest sensitivity and specificity value was $3.573 \mathrm{mg} / \mathrm{L}$ with a sensitivity of 0.947 and a specificity of $0.833{ }^{19}$

According to the International Pediatric Nephrology Association (IPNA), the hs-CRP examination has not become a routine examination carried out in monitoring 
steroid-resistant NS patients. ${ }^{20}$ However, SN patients must undergo a routine laboratory to assess risk factors for atherosclerosis, not only lipid profiles and fractions, but hs- CRP. A systematic examination should be continued as to the intima-media thickness of the carotid arteries in NS patients, especially in patients with frequent relapses or steroid resistance. ${ }^{11}$

\section{CONCLUSIONS}

There was no significant difference in the value of hs-CRP in steroid sensitive NS patients with steroid-resistant NS. In steroid sensitive NS patients, it was found that the average age was 8.4 years and the sex was more male than female. In steroid-resistant NS patients, it was found that the average age was 10.4 years and the sex was more male than female. There is no difference in the mean values of hematological parameters, blood sugar levels, kidney function, albumin, urine protein and lipid profiles (cholesterol, HDL, LDL and triglycerides) in patients with steroid-sensitive NS and steroid-resistant NS.

\section{ACKNOWLEDGEMENTS}

The author thanks to all clinical staff of Nephrology division, Adam Malik Hospital who were involved and contributed for the completion of this study.

\section{REFERENCES}

1. Park SJ, Shin JI. Complications of nephrotic syndrome. Korean J Pediatr. 2011; 54:322-28.

2. Noone DG, Iijima K, Parekh R. Idiopathic nephrotic syndrome in children. The Lancet. 2108:1-14.

3. Sinha A, Bagga A. Nephrotic Syndrome. Indian J Pediatr. 2012;79(8):1045-1055.

4. Eddy AA, Symons JM. Nephrotic syndrome in childhood. The Lancet. 2003; 362:629-39.

5. Noer MS. Sindrom nefrotik idiopatik. Kompendium nefrologi anak. UKK Nefrologi. Jakarta: Ikatan Dokter Anak Indonesia; 2011. h.72-88.

6. Binti Hamdan, Nur Farhana Puteri. Insidensi sindrom nefrotik inisial pada anak di RSUP. H. Adam Malik, Medan dari tahun 2011 sampai 2012.[skripsi]. Medan: Universitas Sumatera Utara, 2016.

7. Zilleruelo G, Hsia SL, Freundlich M, Gorman HM, Strauss J. Persistence of serum lipid abnormalities in children with idiopathic nephrotic syndrome. J Pediatr. 1984; 104:61-64.

8. Bushara HMM, Ahmed EM. Hyperlipidemia in children with nephrotic syndrome in khartoum state. A thesis to be submitted in partial fulfillment for the requirement of the degree of Clinical MD in Paediatrics \& Child Health.2006:1-129.

9. Rheault MN. Nephrotic syndrome. Clinical Pediatric Nephrology. 2017; 3:285-304.

10. Shiravastava AK, Singh HV, Raizada A, Singh SK. C-reactive protein, inflammation and coronary heart disease. Egyptian Heart J.2015; 67:89-97.

11. Kniazewska MH, Obuchowicz AK, Wielkoszyński T, Zmudzińska-Kitczak J, Urban K, Marek M, et al. Atherosclerosis risk factors in young patients formerly treated for idiopathic nephrotic syndrome. Pediatr Nephrol. 2009 Mar;24(3):549-54.

12. Banh TH, Hussain-Shamsy N, Patel V, Vasilevska-Ristovska J, Borges K, Sibbald C, et al. Ethnic differences in incidence and outcomes of childhood nephrotic syndrome. Clin J Am Soc Nephrol. 2016;11:

13. Zhou J, Shi F, Xun W. Leptin, hs-CRP, IL-18 and urinary protein before and after treatment of children with nephrotic syndrome. Exp Ther Med. 2018; 15:4426-30.

14. Kocyigit I, Yilmaz MI, Simsek Y, Unal A, Sipahioglu MH, Eroglu E, et al. The role of platelet activation in determining response to therapy in patients with primary nephrotic syndrome. Platelets. 2013; 24(6): 474-9.

15. Lawang SA, Rauf S, Lisal JS, Albar A, Daud D. Plasma lipids as risk factors in relapsing nephrotic syndrome. Paediatr Indones 2008; 48:6. 
16. Lauer RM, Barnes LA, Clark R, Deckelbaum RJ, Finberg L, Kwiterovich PO, et al. National cholesterol education program (NCEP): highlights of the report the expert panel on blood cholesterol levels in children and adolescents. Pediatrics 1992;89(3):495-6.

17. Hopper J, Ryan P, Lee JC. Lipoid nephrosis in 31 adult patients: Renal biopsy study by light, electron and fluorescence microscopy with experience in treatment. Medicine 1970;49:321-341.

18. Hribal ML, Fiorentino TS, Sesti G. Role of C Reactive protein (CRP) in leptin resistance. Current Pharmaceutical Design. 2014; 20:609-15.

19. Horas W. Peranan high sensitivity c-reactive protein terhadap tingkat keparahan lesi koroner pada pasien dengan penyakit jantung koroner stabil. [Tesis]. Makassar: Universitas Hasanuddin Makassar, 2017.

20. Trautmann A, Vivarelli M, Samuel S, Gipson D, Sinha A, Schaefer F, et al. IPNA clinical practice recommendation for the diagnosis and management of children with steroid resistant nephrotic syndrome. Pediatr nephrol 2020; 35: 1529-61.

Table 1. Characteristic Demographics of subjects

Characteristic Steroid sensitive NS Steroid resistant NS
$(\mathrm{n}=18)$ $(n=18)$

$\operatorname{Sex}(\mathrm{n} / \%)$

Male

Female

Age, years, (mean/SD)

Body weight, kg, (mean/SD)

Body length, cm, (mean/SD)
$13(72)$

$5(27.7)$

$8.4(4.8)$

$28.9(13.1)$

$123.2(24.6)$
$12(66.6)$

$6(33.3)$

$10.4(4.7)$

$37.2(16.1)$

$135.8(22.7)$

Table 2. Differences of hematological parameters in subjects

\begin{tabular}{lccc}
\hline \multicolumn{1}{c}{ Characteristic } & $\begin{array}{c}\text { Steroid sensitive } \\
\text { NS }(\mathrm{n}=18)\end{array}$ & $\begin{array}{c}\text { Steroid resistant } \\
\text { NS }(\mathrm{n}=18)\end{array}$ & $\mathrm{P}$ \\
\hline $\begin{array}{l}\text { Hemoglobin, g/dL, (median/min- } \\
\text { maks) }\end{array}$ & $12.3(8.1-19.2)$ & $14(8.3-17.4)$ & 0.084 \\
$\begin{array}{l}\text { Leukocytes, } / \mu \mathrm{L},(\text { median/min- } \\
\text { maks) }\end{array}$ & $13,270(5,750-$ & $10,420(6,040-$ & 0.429 \\
\hline
\end{tabular}

Mann-Whitney

Table 3. Differences of blood chemistry parameters and urine protein in subjects

\begin{tabular}{lccc}
\hline \multicolumn{1}{c}{ Characteristic } & $\begin{array}{c}\text { Steroid sensitive } \\
\text { NS (n=18) }\end{array}$ & $\begin{array}{c}\text { Steroid resistant } \\
\text { NS (n= 18) }\end{array}$ & P \\
\hline $\begin{array}{l}\text { Blood glucose, mg/dL, } \\
\text { (median/min-maks) }\end{array}$ & $95(72-121)$ & $89(69-138)$ & $0.248^{\mathrm{a}}$ \\
$\begin{array}{l}\text { Ureum, mg/dL, (median/min- } \\
\text { maks) }\end{array}$ & $29(9-268)$ & $25(9-83)$ & $0.350^{\mathrm{a}}$ \\
$\begin{array}{l}\text { Creatinine, } \mathrm{mg} / \mathrm{dL},(\text { median/min- } \\
\text { maks) }\end{array}$ & $0.5(0.2-2.2)$ & $0.5(0.4-1)$ & $0.812^{\mathrm{a}}$ \\
$\begin{array}{l}\text { Urine protein urin, (median/min- } \\
\text { maks) }\end{array}$ & $3(1-4)$ & $3(1-4)$ & $1.000^{\mathrm{a}}$ \\
\begin{tabular}{l} 
Albumin, g/dL, (mean/SD) \\
\hline
\end{tabular} & $3(0.8)$ & $3.4(0.9)$ & $0.202^{\mathrm{b}}$ \\
\hline
\end{tabular}

${ }^{\text {a Mann-Whitney }}$ 
${ }^{\mathrm{b}}$ Unpaired t test

Table 4. Differences of lipid profiles in subjects

\begin{tabular}{lccc}
\hline \multicolumn{1}{c}{ Characteristic } & $\begin{array}{c}\text { Steroid sensitive } \\
\text { NS }(\mathrm{n}=18)\end{array}$ & $\begin{array}{c}\text { Steroid resistant } \\
\text { NS }(\mathrm{n}=18)\end{array}$ & $\mathrm{p}$ \\
\hline $\begin{array}{l}\text { Total cholesterol, mg/dL, } \\
\text { (median/min-maks) }\end{array}$ & $225(154-565)$ & $232(185-622)$ & 0.527 \\
$\begin{array}{l}\text { Triglycerides, mg/dL, } \\
\text { (median/min-maks) }\end{array}$ & $204.5(54-520)$ & $154.5(57-628)$ & 0.569 \\
HDL, mg/dL, (median/min-maks) & $49.5(34-63)$ & $46.5(21-70)$ & 0.303 \\
LDL, mg/dL, (median/min-maks) & $141(99-461)$ & $164.5(105-716)$ & 0.248 \\
\hline
\end{tabular}

Table 5. Differences of hs-CRP in steroid sensitive nephrotic syndrome patients with steroid resistance

\begin{tabular}{cccc}
\hline Parameter & Group & $\begin{array}{c}\text { Median } \\
(\text { minimum-maksimum })\end{array}$ & p \\
\hline hs-CRP, mg/dL & Steroid sensitive NS & $0.10(0.0-2.6)$ & $0.529 *$ \\
& Steroid resistant NS & $0.05(0.0-2.3)$ & \\
& & &
\end{tabular}

